\title{
Development of Intercultural Competence as a Result of Internationalization-at- Home Initiatives in Japan's Top Global Universities
}

\author{
Ana Sofia Hofmeyr \\ Osaka University, Japan; Kansai University, Japan \\ Email: ahofmeyr@kansai-u.ac.jp \\ Address: Faculty of Foreign Language Studies, Kansai University, 3 Chome-3-35 Yamatecho, Suita, Osaka 564-8680, Japan
}

\section{Introduction}

The internationalization of higher education institutions in the past three decades has grown parallel to an increasing need to foster interculturally competent graduates capable of addressing global challenges and advancing economic development (Deardorff and Jones 2012; Yamamoto 2018). In Japan, internationalization has been strongly encouraged, promoted, and funded by the government (Horie 2002; Yonezawa 2009). Through programs such as the "Global 30" and the "Top Global University Project", internationalization has become intimately linked to the fostering of "global human resources" (CPHRGD 2011).

While internationalization strategies in Japan have historically emphasized mobility programs (MEXT 2011; Burgess 2015), challenges posed mainly by financial reasons, safety concerns, and an inflexible job-hunting system (Bradford 2017) have led to a decrease in the number of Japanese students going abroad in mid- to long-term programs (JAOS 2018). Moreover, in recent years scholars worldwide have come to acknowledge that it is not mobility but significant intercultural experiences, either at home or abroad, that are fundamental to the development of intercultural competence (Fantini, Arias-Galicia and Guay 2001; Deardorff and Hunter 2006).

One alternative strategy adopted by the Japanese government in an attempt to internationalize domestic campuses and provide such experiences is the large intake of international students (Kuwamura 2009), thus reaching a much larger number of domestic students than mobility programs. However, a misplaced emphasis on scores of international students rather than on meaningful interaction (Knight 2011) has impaired the success of internationalization-at-home strategies and led to missed opportunities for meaningful multicultural contact (Ward 2001; Deardorff and Hunter 2006; Morita 2012a).

Intercultural initiatives that intentionally bring together domestic and international students emerge from previous research as fundamental to the development of intercultural competence by allowing students to actively and consciously be exposed to and engage with difference (Deardorff and Hunter 2006; Bennett 2009). Yet, not only do the concepts of global human resources and of intercultural competence remain unclear, to this date relatively few studies have been conducted on internationalization-at-home initiatives from the perspective of domestic students, including in Japan (Morita 2012a; Morita 2012b; Haswell 2014).

\section{Research Focus and Methodology}

In order to identify the potential effects of internationalization-at-home strategies on the development of intercultural competence in domestic students, three main research questions were identified:

1. What is intercultural competence in the Japanese higher education context?

2. Can internationalization-at-home generate intercultural competence in domestic students?

3. If internationalization-at-home is able to generate intercultural competence in domestic students, what are the circumstances for its production? 
To answer the first question, the researcher conducted an analysis of policy and promotional documents published by the Japanese government and by the 37 universities belonging to the Top Global University Project, considered leaders of internationalization in Japan, in order to identify the components of intercultural competence marketed as desirable products of internationalized education. The data collected was then converted into the theoretical framework of analysis.

To answer the second and third questions, the researcher has opted to conduct an exploratory, longitudinal, mixedmethods study with over 150 first-year undergraduate students across a one-year period at two Top Global universities for three reasons. First, intercultural competence is widely regarded as an ongoing, lifelong process (Deardorff 2011), and should therefore be assessed over a period of time. Second, a multi-method approach which goes beyond indirect measures, such as self-report instruments, is generally considered a more valuable form of assessment (Deardorff 2009; Fantini 2009). Finally, first-year students will generally have had less contact with foreign cultures, thus allowing for better control of extraneous variables influencing the development of intercultural competence.

A total of three surveys will be conducted - one at the beginning of the first semester, to establish an intercultural competence baseline, and two at the end of the first and second semesters respectively, to measure change. The surveys will account for different variables which will be used in correlation analysis, such as percentage of international students on campus, domestic students' prior experience abroad, and intercultural program participation. The surveys will also include self-report questions on a 6-point Likert scale concerning intercultural attitudes, knowledge, and skills, as well as open-ended answers to critical incidents focused on intercultural interactions.

The surveys will be administered to students who participate in intercultural initiatives alongside international students, such as buddy programs and culturally-mixed dormitories, as well as to a control group made of students who do not participate in either formal or informal intercultural interventions. Additionally, semi-structed interviews will be conducted with a limited number of participants to further investigate the factors and circumstances advancing or hindering the development of intercultural competence in domestic campuses.

\section{Theoretical Framework}

The assessment of intercultural competence has been thoroughly theorized and a wide range of assessment models have been developed (Spitzberg and Changnon 2009). However, few of these models are tailored to universities and their internationalization process, and even fewer take into consideration Eastern approaches to internationalization or globally competent graduates. It has also been pointed out that it is essential for the institutional context to be taken into consideration and that assessment should begin with a review of institutional mission statement and goals (Sternberger, Pysarchik, Yun, and Deardorff 2009; Deardorff and van Gaalen 2012).

For these reasons, the researcher designed a theoretical framework of analysis that combines the components of intercultural competence identified in Deardorff's delphi study of intercultural competence (Deardorff 2006), based on perceptions among scholars and educational stakeholders, with competencies identified by the Japanese government and Top Global universities, as central to the concept of global human resources in the Japanese higher education context (CPHRGD 2011; MEXT 2011; MEXT 2014; MEXT 2017). Deardorff's model, despite being chiefly based on Western perceptions of intercultural competence, provides a clear framework of comparison through which shared components as well as idiosyncrasies belonging to Japanese higher education can be more easily identified.

The 16 components of intercultural competence that were found to be pertinent in both Deardorff's model and in the Japanese context were converted by the researcher into self-report statements assessed in a Likert scale as well as used as the basis to code the open-ended critical incident questions in the surveys.

\section{Significance}


Reports have suggested that the number of Japanese going abroad in mid- to long-term programs is decreasing. Simultaneously, the number of incoming international students continues to increase (JASSO 2017). Internationalization-at-home thus emerges as a viable, more inclusive alternative to study abroad in the development of interculturally competent human resources.

Through the assessment of the impact of at-home initiatives on domestic students over a one-year period, this research aims to identify the factors promoting and/or hindering the development of intercultural competence in domestic students. Ultimately, it is expected to provide a basis for the improvement of internationalization-at-home strategies, in general, and for the optimization of the impact of programs that promote meaningful interaction between international and domestic students, in particular.

\section{References}

Bennett, Janet M. 2009. "Cultivating Intercultural Competence." In The SAGE Handbook of Intercultural Competence, edited by Darla K. Deardorff, 121-140. Thousand Oaks: SAGE.

Bradford, Annette. 2017. "Barriers to Japanese Student Mobility." The Bulletin of Arts and Sciences Meiji University [明治大学教養論集] 523: 99-118.

Burgess, Chris. 2015. "To globalise or not to globalise? 'Inward-looking youth' as Scapegoats for Japan's Failure to Secure and Cultivate 'Global Human Resources'." Globalisation, Societies and Education 13(4): 487-507.

Deardorff, Darla K. 2011. "Assessing Intercultural Competence." New Directions for Institutional Research 149: 65-79. Deardorff, Darla K. 2006. "Identification and Assessment of Intercultural Competence as a Student Outcome of Internationalization." Journal of Studies in International Education 10 (3): 241-266.

Deardorff, Darla K. 2009. "Implementing Intercultural Competence Assessment." In The SAGE Handbook of Intercultural Competence, edited by Darla K. Deardorff, 477-491. Thousand Oaks: SAGE.

Deardorff, Darla K, and Adinda van Gaalen. 2012. "Outcomes Assessment in the Internationalization of Higher Education." In The SAGE Handbook of International Higher Education, edited by Darla K Deardorff, Hans de Wit, John D Heyl, and Tony Adams, 167-190. SAGE.

Deardorff, Darla K, and Elspeth Jones. 2012. "Intercultural Competence: An Emerging Focus in International Higher Education." In The SAGE Handbook of International Higher Education, edited by Darla K Deardorff, Hans de Wit, John D Heyl and Tony Adams, 283-303. SAGE.

Deardorff, Darla K., and William Hunter. 2006. "Educating Global-Ready Graduates." International Educator 15(3): 72-83.

Fantini, Alvino E. 2009. "Assessing Intercultural Competence: Issues and Tools." In The SAGE Handbook of Intercultural Competence, edited by Darla K. Deardorff, 456-476. Thousand Oaks: SAGE.

Fantini, Alvino E., Fernando Arias-Galicia, and Daniel Guay. 2001. Globalization and 21st Century Competencies: Challenges for North American Higher Education. Boulder, Colorado: Western Interstate Commission for Higher Education.

Haswell, Christopher G. 2014. "Issues related to the internationalizing of Japanese universities." JALT2013 Conference Proceedings: 28-37.

Horie, Miki. 2002. "The Internationalization of Higher Education in Japan in the 1990s: A Reconsideration." Higher Education 43: 65-84.

JAOS. 2018. "JAOS 2017 Survey on the Number of Japanese Studying Abroad." https://www.jaos.or.jp/wpcontent/uploads/2018/01/JAOS-Survey-2017_Number-of-Japanese-studying-abroad180124.pdf.

JASSO. $\quad 2017 . \quad$ "International Students $\quad$ in $\quad$ Japan http://www.jasso.go.jp/en/about/statistics/intl_student/data2017.html. 
Knight, Jane. 2011. "Five Myths about Internationalization." International Higher Education 62: 14-15.

Kuwamura, Akira. 2009. "The Challenges of Increasing Capacity and Diversity in Japanese Higher Education Through

Proactive Recruitment Strategies." Journal of Studies in International Education 13(2): 189-202.

MEXT. 2011. "Project for Establishing University Network for Internationalization - Global 30 -."

MEXT. 2014. "Selection for the FY 2014 Top Global University Project."

MEXT. 2017. Top Global University Project. Accessed July 4, 2018. https://tgu.mext.go.jp/en/index.html.

Morita, Liang. 2012a. "English and Intercultural Interaction in the Internationalisation of a Japanese University." Journal of Intercultural Communication 30.

Morita, Liang. 2012b. "Internationalisation and Intercultural Interaction at a Japanese University - A Continuing Inquiry." Electronic Journal of Contemporary Japanese $\quad$ Studies $12(2)$. https://www.japanesestudies.org.uk/ejcjs/vol12/iss2/morita.html.

Sternberger, Lee, Dawn Thorndike Pysarchik, Zee-Sun Yun, and Darla Deardorff. 2009. "Designing a Model for International Learning Assessment." Diversity and Democracy 12 (1). https://www.aacu.org/publicationsresearch/periodicals/designing-model-international-learning-assessment.

The Council on Promotion of Human Resource for Globalization Development (CPHRGD). 2011. "An Interim Report of The Council on Promotion of Human Resource for Gloabalization Development." http://www.kantei.go.jp/jp/singi/global/1206011interim_report.pdf.

Ward, Colleen. 2001. The Impact of International Students on Domestic Students and Host Institutions. Wellington: New Zealand Ministry of Education.

Yamamoto, Beverley Anne. 2018. "The Internationalization of Japanese Higher Education: Incremental Change in a Dynamic Global Environment." In Japanese Education in a Global Age: Sociological Reflections and Future Directions, edited by Akiyoshi Yonezawa, Yuto Kitamura, Beverley Yamamoto, and Tomoko Tokunaga, 221-239. Springer.

Yonezawa, Akiyoshi. 2009. "The Internationalization of Japanese Higher Education: Policy Debates and Realities." Nagoya Journal of Higher Education 9: 199-218. 